\title{
A cross-sectional study on asymptomatic bacteriuria among antenatal women attending an urban tertiary health care center in Southern India
}

\author{
Priya Paari*, Sindhuja T. P., Shanthi Dhinakaran, Christina Mary P. Paul
}

Department of Obstetrics and Gynecology, ACS Medical College and Hospital, Poonamallee High Road, Vellapanchavadi, Chennai, Tamil Nadu, India

Received: 31 July 2017

Accepted: 01 September 2017

*Correspondence:

Dr. Priya Paari,

E-mail: paariv2012@gmail.com

Copyright: (c) the author(s), publisher and licensee Medip Academy. This is an open-access article distributed under the terms of the Creative Commons Attribution Non-Commercial License, which permits unrestricted non-commercial use, distribution, and reproduction in any medium, provided the original work is properly cited.

\section{ABSTRACT}

Background: Asymptomatic bacteriuria (ASB) in pregnancy is a treatable risk factor for preterm delivery. India accounts for the highest preterm birth incidence in the world according to the WHO census released in November 2016. This study was aimed at finding the prevalence of asymptomatic bacteriuria, the spectrum of bacteria involved and the susceptibility pattern for the antimicrobials in the antenatal women attending a tertiary care hospital in urban Southern India.

Methods: One hundred and eighty ante-natal patients without symptoms of ongoing urinary tract infection were enrolled to this study. Clean midstream urine sample was collected in a wide mouthed container and sample was analyzed by standardized microbiological testing techniques.

Results: Out of the 180 ante-natal women included in the study, 11(6.1\%) patients were found to have insignificant bacteriuria and $38(21.1 \%$ ) had a significant bacteriuria. E. coli was the most frequently isolated organism and about $95 \%$ of the organisms were sensitive to Nitrofurantoin.

Conclusions: More than a fifth of all pregnant women have ASB and E. coli is the most frequent pathogen encountered.

Keywords: Antimicrobial susceptibility pattern, Asymptomatic bacteriuria, Preterm labour, Urinary tract infection

\section{INTRODUCTION}

Urinary tract infection (UTI) during pregnancy is quite common and can affect up to a fifth of all pregnant women. ${ }^{1,2}$ Conventionally, if the patient is asymptomatic but the urine still contains a significant number (i.e. > $10^{5}$ ) colony-forming units $(\mathrm{CFU}) / \mathrm{mL}$ of bacteria, this condition is called as asymptomatic bacteriuria (ASB). ${ }^{3}$ Several physiological, immunological and anatomical changes that occur during the pregnancy as well as the other risk factors like age, parity, personal hygiene and sexual activity predispose the women to develop ASB and are well described in literature. ${ }^{3-6}$ Prevalence of ASB in pregnant women is thought to be about $2-11 \% .^{4,7,8} \mathrm{ASB}$ in pregnancy poses a high risk for low birth weight, preterm deliveries, acute pyelonephritis and acute cystitis. 9,10

These cases account for $70 \%$ of all cases of symptomatic urinary tract infections (UTI) among unscreened pregnant women. The infection of the lower genital tract ascends above via the short urethra $(4 \mathrm{~cm})$ and colonises in the urinary tract. Pregnancy is an immune compromised state which along with the action of progesterone related increased vesico-uretral reflux serves as a higher risk for development of ASB. Glycosuria and aminoaciduria in pregnancy are additional risk factors for the development of ASB. ${ }^{11,12}$ 


\section{Pathophysiology}

Infections result from ascending colonization of the urinary tract, primarily by existing vaginal, perineal, and fecal flora. Various maternal physiologic and anatomic factors predispose to ascending infection. Such factors include urinary retention caused by the weight of the enlarging uterus and urinary stasis due to progesteroneinduced urethral smooth muscle relaxation.

Loss of urethral tone combined with increased urinary tract volume results in urinary stasis, which can lead to dilatation of the ureters, renal pelvis, and calyces. Urinary stasis and the presence of vesicoureteral reflux predispose some women to upper UTI. Although the influence of progesterone causes relative dilatation of the ureters, ureteral tone progressively increases above the pelvic brim during pregnancy. However, whether bladder pressure increases or decreases during pregnancy is controversial. ${ }^{11}$ Glycosuria and an increase in levels of urinary amino acids (aminoaciduria) during pregnancy are additional factors that lead to UTI. Presence of aminoaciduria has been postulated to affect the adherence of Escherichia coli to the urothelium. ${ }^{12}$

\section{METHODS}

180 women attending the outpatient department for regular ante-natal checkup were included in the study done between August 2016 and December 2016. Antenatal women of age 18-40 years who consented for the study were included. Age, parity, trimester of the pregnancy, socio-economic status (Kuppusamy classification) and the presence of any ante-natal complications were noted. Women with symptoms of UTI, recent diagnosis of UTI, known abnormalities in the urinary tract and women on antibiotics for any reason were excluded. Study participants were educated about correct method of collecting the midstream urine in a sterile wide mouthed container; the samples were processed within 4 hours of specimen collection. Urine samples were examined macroscopically for the colour, cloudiness, blood staining and deposits. Urine samples were submitted for microscopic and biochemical analysis and for culture and sensitivity. About $5 \mathrm{~mL}$ of well-mixed urine sample was centrifuged at $3000 \mathrm{rpm}$ for $10 \mathrm{~min}$. Light microscopic examination of the obtained sediment was then to look for pus cells, red blood cells, casts, crystals and yeast-like cells. Excess of epithelial cells are indicative of an inappropriate collection of the sample. The presence of 10 pus cells/cc or more was regarded as pyuria. Drops of the urine were then applied to microscope slides, allowed to air dry, stained with Gram stain, and examined microscopically. The supernatant of the centrifuged urine was then subjected to tests for detecting nitrite and leucocyte esterase in the urine using Combi screen 10 urinalysis strips. The presence of positive nitrites and leucocyte esterase tests with presence of > 30 pus cells/cc and/or positive Gram stain was considered as suggestive active UTI.
A quantity of $0.01 \mathrm{~mL}$ of urine sample was inoculated on to CLED agar and Blood agar plates for semi-quantitative cultures using standard loop. The plates were incubated at $37^{\circ} \mathrm{C}$ overnight in an incubator. Bacterial counts were performed in a colony counter. Bacterial counts of more than $10^{5}$ organisms $/ \mathrm{mL}$ were considered as significant bacteriuria. Lower bacterial counts were considered insignificant and growth of more than two types of organisms was considered as contamination. For cultures with no or insignificant bacterial growths, incubation was continued for a further 24 hours. Antibiotic susceptibility pattern was checked and the patient was treated with appropriate antibiotics if there was a significant colony count of pathological microbes.

Ethical committee approval was obtained from the institutional ethics committee, A.C.S. medical college and hospital at the beginning of the study. Informed consent was obtained from all the participants who enrolled for the study.

\section{RESULTS}

Thirty eight out of the 180 women tested had significant bacteriuria $(21.1 \%)$ while another 11 (6.1\%) had insignificant bacteriuria. The distribution of the patients with significant bacteriuria amongst the various groups is depicted in Table 1.

The various bacteria isolated in ASB patients and their frequency is shown in Table 2. Nitrofurantoin was the most common antimicrobial against all the organisms. Among the antibacterial susceptibility pattern except for streptococcus all the other organisms were found to be sensitive to nitrofurantoin.

\section{DISCUSSION}

Asymptomatic bacteriuria when left out without treatment may progress to acute pyelonephritis in 20-30 $\%$ cases (grade A recommendation). ${ }^{3}$ The US task force recommends screening for asymptomatic bacteriuria at 12 to 16 weeks gestation or at the first antenatal visit. At least one urine culture should be performed at the end of first trimester. ${ }^{3}$

In this study, the prevalence of bacteriuria was $21.1 \%$ which was similar to higher prevalence rates of $26 \%$ and $45.3 \%$ as in studies by Neupane et al and Imade et al. ${ }^{13,14}$ Alghalibi et al reported a higher prevalence of ASB among women aged in the group of 21-25 years, but our study did not find any statistically different incidence between the two age groups studied. ${ }^{15}$ Multiparous women in this study were noticed to have a slightly higher but statistically insignificant prevalence of ASB. This was identical to other studies as quoted in Roy et al $(51 \%)$ the higher risk of development of ASB in multiparous women is attributed to lax perineum and higher risk of development of diabetes in recurrent pregnancies. ${ }^{16}$ 
Table 1: ASB distribution among various clinical groups is depicted.

\begin{tabular}{|c|c|c|c|c|}
\hline Variable & $\begin{array}{l}\text { Classification of variable } \\
\text { (number of people in the } \\
\text { group out of 180) }\end{array}$ & $\begin{array}{l}\text { Number of antenatal women with } \\
\text { significant bacteriuria (out of } 38 \text { ) }\end{array}$ & $\begin{array}{l}\text { Odds ratio } \\
\text { (95\% C.I of odds } \\
\text { ratio) }\end{array}$ & P-value \\
\hline \multirow{2}{*}{ Age } & $\geq 30$ years $(53)$ & 15 & $1.78(0.84-3.78)$ & \multirow{2}{*}{0.13} \\
\hline & $18-29$ years $(127)$ & 23 & 1.00 & \\
\hline \multirow{2}{*}{ Parity } & Multipara (116) & 25 & $1.08(0.51-2.23)$ & \multirow{2}{*}{0.85} \\
\hline & Primi (64) & 13 & 1.00 & \\
\hline \multirow{2}{*}{$\begin{array}{l}\text { Socio-economic } \\
\text { status }\end{array}$} & Class III, IV and V (105) & 26 & $1.73(0.81-3.69)$ & \multirow{2}{*}{0.16} \\
\hline & Class I and II (75) & 12 & 1.00 & \\
\hline \multirow{2}{*}{ Trimester } & I and II trimester (127) & 31 & $2.12(0.87-5.18)$ & \multirow{2}{*}{0.09} \\
\hline & III trimester (53) & 7 & 1.00 & \\
\hline \multirow{2}{*}{$\begin{array}{l}\text { Antenatal } \\
\text { complications }\end{array}$} & Present (75) & 20 & $1.76(0.85-3.61)$ & \multirow{2}{*}{0.12} \\
\hline & Nil (105) & 18 & 1.00 & \\
\hline
\end{tabular}

Table 2: The frequency of the organisms detected on the culture of the urine in patients with ASB is shown.

\begin{tabular}{|l|l|l|}
\hline Organism & Number of patients & $\%$ \\
\hline E. Coli & 11 & 28.9 \\
\hline Enterococci species & 8 & 21 \\
\hline Klebsiella species & 7 & 18.4 \\
\hline Pseudomonas & 3 & 7.8 \\
\hline Streptococcus species & 2 & 5.2 \\
\hline Staphylococcus species & 2 & 5.2 \\
\hline Mixed & 5 & 13.1 \\
\hline Total & $\mathbf{3 8}$ & $\mathbf{1 0 0}$ \\
\hline
\end{tabular}

In contrast to the previous studies lower socioeconomic status was found to have lower incidence of ASB and the reason for the same is unclear.

E. coli was the most prevalent microbe found among the ASB cases in our study (28\% cases), as was the case in the studies by Demilie T et al $(45.0 \%)$ and Obirikorang et al $(36.8 \%) .{ }^{17,18}$ The major contributing factor for isolating higher rate of E.coli is due to urine stasis in pregnancy which favors for E.coli strain colonization. ${ }^{9-11}$ Another reason could be due to poor genital hygiene by pregnant women who may find it difficult due to the gravid uterus to clean their perineal region properly after defecation or voiding. Most of the microbes were susceptible to Nitrofurantoin which was similar to other studies which had a predominance of E. coli. ${ }^{19,20}$

A Cochrane review concluded that the antibiotic treatment in pregnant women with ASB reduces the risk of development of pyelonephritis, low birth weight and preterm delivery. ${ }^{19}$ The WHO fact sheet reviewed in November 2016 showed 15 million pre-term births worldwide with India leading the pack with more than 3.5 million occurrences per year. As ASB has a role in preterm births in pregnant women, improved awareness amongst pregnant women, early identification and appropriate anti-microbial treatment would go a long way in decreasing the incidence of pre-term births and its associated complications.

\section{CONCLUSION}

The above study has confirmed the common prevalence of ASB in ante-natal women in urban Southern India. This indicates the importance of routine screening for ASB in all antenatal women and treatment with specific antibiotics should be commenced with appropriate antimicrobial sensitivity pattern.

Funding: No funding sources

Conflict of interest: None declared

Ethical approval: The study was approved by the Institutional Ethics Committee

\section{REFERENCES}

1. Parveen K, Momen A, Begum AA. Prevalence of urinary tract infection during pregnancy. J Dhaka Natl Med Coll Hosp. 2012;17:8-12.

2. Ebidor UL, Tolulope A, Deborah O. Urinary tract infection amongst pregnant women in Amassoma, Southern Nigeria. Afr J Microbiol Res. 2015;9:3559.

3. U. S. preventive service task force. Screening for assymptomatic bacteriuria in adults; U.S. preventive services task force reaffirmation recommendation statement. Ann intern med. 2008;149(1):43-7.

4. Ghafari M, Baigi V, Cheraghi Z. The prevalence of asymptomatic bacteriuria in Iranian pregnant women: a systematic review and meta-analysis. PLoS One. 2016;11:e0158031.

5. Jain V, Das V, Agarwal A. Asymptomatic bacteriuria and obstetric outcome following treatment in early versus late pregnancy in north Indian women. Indian J Med Res. 2013;137:753-8.

6. Muharram SH, Ghazali SNB, Yaakub HR. A preliminary assessment of asymptomatic bacteriuria 
of pregnancy in Brunei Darussalam. Malaysian $\mathbf{J}$ Med Sci. 2014;21:34-9.

7. Smaill F, Vazquez JC. Antibiotics for asymptomatic bacteriuria in pregnancy. Cochrane Database Syst Rev. 2007;(2):CD000490.

8. Hazhir S. Asymptomatic bacteriuria in pregnant women. Urol J. 2007;4:24-7.

9. Le J, Briggs GG, McKeown A. Urinary tract infections during pregnancy. Urin Tract Infect $\mathrm{J}$. 2004;3:1-28.

10. Schnarr J, Smaill F. Asymptomatic bacteriuria and symptomatic urinary tract infections in pregnancy. Eur J Clin Invest. 2008;38(Suppl 2):50-7.

11. Patterson TF, Andriole VT. Detection, significance, and therapy of bacteriuria in pregnancy. Update in the managed health care era. Infect Dis Clin North Am. 1997;11(3):593-608.

12. Worthington S, Christodoulou J, Wilcken B, Peat B. Pregnancy and argininosuccinic aciduria. J Inherit Metab Dis. 1996;19(5):621-3.

13. Neupane MS, Dhakal KS, Neupane HC, Adhikari S, Aryal B. assymptomatic bacteruria among pregnant women attending the outpatient clinics of Chitwan medical college teaching hospital in chitwan, Nepal. IRJP. 2012;3(11):78-80.

14. Imade PE, Izekor PE, Egahfona NO, Enabuele OI, Ohori E. Assymptomatic bacteriuria among pregnant women. Nam J Med Sci. 2010;2(6):263-6.

15. Alighabi SM, Al-jaufy A, Al-moayad E. Bacterial urinary tract infection ami-ong pregnant women in Sana'a city Yemen. Arab Gulf J Sci Res. 2007;25:23-31.
16. Roy SK, Sinha GR, Qudros MA, A study of bacteriuria in pregnancy. J Obstet Gynecol India. 1974;24:244-51.

17. Demilie T, Beyene G, Melaku S, Tsegaye W. Urinary bacterial profile and antibiotic susceptibility pattern among pregnant women in North West Ethiopia. Ethiop J Health Sci. 2012;22(2):121-8.

18. Obirikorang C, Quaye L, Bio FY, Amidu N, Acheampong I, Addo K. Asymptomatic Bacteriuria among Pregnant Women Attending Antenatal Clinic at the University Hospital, Kumasi, Ghana. J Med Biomed Sci. 2012;1(1):38-44.

19. Smail FM, Vazquez JC. Antibiotics for assymptomatic bacteriuria in pregnancy. Cochrane Database Syst Rev. 2015;CD000490.

20. Assefa A, Asrat D, Woldeamanuel Y, G/Hiwot Y, Abdella A, Melesse T. Bacterial profile and drug susceptibility pattern of urinary tract infection in pregnant women at Tikur Anbessa Specialized Hospital, Addis Ababa, Ethiopia. Ethiop Med J. 2008;46:227-35.

Cite this article as: Paari P, Sindhuja TP, Dhinakaran S, Paul CMP. A cross-sectional study on asymptomatic bacteriuria among antenatal women attending an urban tertiary health care center in Southern India. Int J Reprod Contracept Obstet Gynecol 2017;6:4522-5. 